\title{
Multicriteria evaluation to identify potential areas for level Fanya juu terrace in Central Ethiopia
}

Teshome Betru Tadesse ( $\sim$ beteshe19@gmail.com )

Samara University https://orcid.org/0000-0002-8788-2960

\section{Setiye Abebaw Tefera}

Samara University

Research

Keywords: Soil loss, Level Fanya juu, Suitability, Effectiveness

Posted Date: January 29th, 2021

DOl: https://doi.org/10.21203/rs.3.rs-157737/v1

License: (9) This work is licensed under a Creative Commons Attribution 4.0 International License. Read Full License 


\section{Abstract \\ Background}

The costs of soil erosion are worsening in developing countries. In recent decades of Ethiopia, government sectors and different organizations are working on watershed management campaigns. Despite achievements, soil loss from cropland was not reversed to the productive limit. Therefore, this study attempts to provide information on appropriate sites for level Fanya juu terrace in croplands located in Sodo watershed, central Ethiopia.

\section{Methods}

A spatial layer of soil loss, land use/land cover, slope, and topographic wetness index was managed using a multi-criteria decision analysis (MCDA) system. The suitability class of each layer was made based on the national guideline for soil and water conservation published in 2016. Then the analytical hierarchy process was used to obtain the relative weight of each layer. Finally, the suitability map was generated using the weighted combination method.

\section{Result}

The result shows that $5.5 \%, 3.2 \%$, and $40.8 \%$ of the study area was highly, moderately, and less suitable for level Fanya juu terrace. The remaining is not appropriate at all. Among ground-truthing points collected on an existing terrace, $95 \%$ falls into a less suitable class. Assertively, the MCDA provided imperative information. According to pieces of evidence from level Fanya juu terrace, soil loss is estimated to be reduced by $77 \%$ in areas highly susceptible to soil erosion.

\section{Conclusion}

Appropriate soil and water conservation measures unto applicable place is a central part of watershed management campaigns. In long run, this could be effective where farmers' acceptance, proper execution, and regular maintenance of the structure are kept sustainable. In general, procedure followed and results found in this paper can enable an informed decision on farmer's managed cropland to tackle soil erosion and boost productivity.

\section{Background}

Soil erosion, worsen by land use/ land cover (LU/LC) change is the most common form of land degradation that covers $23 \%$ of Ethiopia (Gebreselassie et al. 2016). A gradual change in LU/LC features was observed sourced from demographic changes, poverty, topography, and land policy those are 
contributing to environmental changes such as biodiversity loss, soil erosion, local climate, and hydrological regime (Desta and Fetene 2020; Musie et al. 2020; Woldesenbet et al. 2020).

In East Africa, the estimated mean annual gross soil loss by water erosion amounts to 4 billion tons with a mean soil loss rate of 6.3 tons/ha/yr, of which $50 \%$ originates from Ethiopia. The study adds, cropland contributed 34.8 tons/ha/yr of mean soil loss in Ethiopia (Almaw et al. 2020).

The share of cropland over the total estimated soil loss accounted for $86 \%$ in the northwest (Alemu and Melesse 2020), 42.6\% in Beshillo catchment, Blue Nile basin (Yesuph and Dagnew 2019), and 11\% in the Meki river sub-basin, central rift valley lake basin (Woldesenbet et al. 2020). However, the rate of soil loss from cultivated land varies between 42 and 300 tons/ha/yr (Gebreselassie et al. 2016). Similarly, the upper catchments of the Meki River sub-basin are facing severe degradation irrespective of the land-use systems (Woldesenbet et al. 2020). The risk of soil erosion in the north-eastern watershed is reported very high to severe levels (Woldesenbet et al. 2020). Besides, $9 \%$ and $6.5 \%$ of the study area stated high to very high soil loss severity levels, respectively (Tadesse and Tefera 2020). In general, the annual cost of land degradation associated with LU/LC is estimated at $\$ 4.3$ billion (Gebreselassie et al. 2016).

Ethiopia has 500-700 years of implementing traditional soil and water conservation (SWC) measures (Wolka et al. 2018) and five decades of experience introducing physical SWC to degraded highlands (Herweg and Ludi 1999). Moreover, during the SWC campaign in the 1970s and 1980s, the transitional government (1980) has promoted farmer's level development and conservation of forest by planting trees within its locality (Federal Negarit Gazeta 1980). In 2010, the Ethiopian government launched a community-managed land restoration program through physical and biological SWC measures in more than 3,000 watersheds aiming to enhance agricultural productivity (Mekuria 2020). Also, the "Green Legacy" initiative has recently launched in June 2019 to rehabilitate degraded lands, increase forest cover and/or services, and tackle food insecurity (Getahun 2020).

Adopted SWC measures deposited $54-74 \%$ of soil loss and boosted soil quality in northern Ethiopian highland (Subhatu et al. 2017). The outcomes of the SWC measure can be explained as 1) short-term (e.g., runoff control and moisture retention) and 2) medium-term (e.g., vegetation cover and soil fertility improvement) biophysical outcomes (Assefa and Kessler 2018). Numerous studies reported the positive short-term return of SWC measures (Wolancho 2015; Saiz et al. 2016; Subhatu et al. 2017, 2018; Assefa and Kessler 2018; Sultan et al. 2018; Wolka et al. 2018; Alemu and Melesse 2020; Teka et al. 2020; Mekonnen 2021). Vegetation cover and soil fertility improvements from SWC measures were also recently attested in Ethiopia (Assefa and Kessler 2018; Teka et al. 2020). Before half a decade, over 3 million hectares of degraded forest land are under area exclosure; smallholder plantations cover 0.8 million ha, and state-owned industrial plantations stagnate at under 0.25 million ha (Lemenih and Kassa 2014). The global community proposed to rehabilitate 350 million hectares by 2030 and Ethiopia made the largest pledge - to restore 22 million hectares (Kassa 2018).

However, despite the efforts made, there is a steadily increasing rate of land degradation (Gebreselassie et al. 2016). Similarly, in recent studies, the effectiveness of SWC measures was not as expected after 4- 
5 decades of execution (Mekonnen 2021). In the Blue Nile basin, where level Fanya juu terrace is implemented, soil loss on treated catchment was not as expected and yet exceeds the tolerable limit in Ethiopian highland (Subhatu et al. 2017, 2018). Despite attentive farmers, the program was hardly effective by farmers who didn't obtain a short-term physical benefit (Assefa and Kessler 2018).

Level Fanya juu terrace is a contour terrace where the riser is built (throw up) at the shoulder of the ditch to block soil movement and enhance soil moisture content which further developed into a bench terrace (Herweg and Ludi 1999; Hurni et al. 2016). Level Fanya juu terrace is reported as, among other SWC measures, the most effective and feasible in (i) reducing soil loss by nearly $70 \%$, retaining sediment, moisture, and soil organic matter at the deposition zone (Herweg and Ludi 1999; Matere et al. 2016; Saiz et al. 2016; Subhatu et al. 2018; Haileslassie et al. 2020; Mekonnen 2021), (ii) reversing slope gradient nearly by half (Subhatu et al. 2018; Sultan et al. 2018; Wolka et al. 2018; Mekonnen 2021), (iii) improved crop yield and household income (Wolka et al. 2018; Haileslassie et al. 2020; Teka et al. 2020; Mekonnen 2021), and vegetation cover (Wolka et al. 2018; Teka et al. 2020).

Nevertheless, the construction of the SWC measure needs a considerable effort to not to below technical standards (Assefa and Kessler 2018) and applicability ranges (Hurni et al. 2016). In almost all parts of Ethiopia, dozens of literature are published on the extent and severity of soil erosion and the urgency of SWC measures. However, to support decision-makers and development agents (DAs), Information on the applicability of SWC measures is rare (Kibret et al. 2020). Therefore, this study has aimed (i) to identify areas suitable for level Fanya juu terrace based on national SWC guidelines using spatial-MCDA technique, and (ii) to estimate potential reduction in soil loss from Fanya juu terrace. This would be pertinent to ease the tasks of DAs (extension workers) and support initiatives working on tackling soil erosion and enhancing agricultural productivity.

\section{Materials And Methods}

\section{Study area description}

Sodo watershed (Fig. 1) is found in the north-eastern tip of Meki river sub-basin, central rift valley lake basin (Desta and Fetene 2020; Tadesse and Tefera 2020). The study watershed is found in the Sodo district with a total population of 181,499 (male 89,869 and Female 91,630) and a density of 205.9 people per square $\mathrm{km}$ (CSA 2019). Hence, the majority of the population are farmers and lives in rural areas.

Sodo watershed covers 8,054 ha. The land use/land cover (LUL/C) feature shared with cropland (61\%), bareland (16\%), woodland (12\%), forest (7\%), settlement/residents (3\%), and enset (Ensete ventricosum Welw. Cheesman) (1\%) (Tadesse and Tefera 2020).

The study area belongs to moist weyna dega and moist dega agro-ecology with a range of elevation 1893-2513 m.a.s.l., rainfall 900-1400 mm, and min-max temperature $10-20^{\circ} \mathrm{C}$ (Hurni et al. 2016; Fentaw and Manaye 2019a). The watershed is dominated by Vertic cambisol by $56 \%$ and the remaining 
takes chromic vertisol by $44 \%$ (Tadesse and Tefera 2020). Nineteen percent of the watershed has less than $5 \%$ slope, $30 \%, 34 \%, 10 \%, 5 \%$, and $1 \%$ of the watershed area in a slope category of $5-10 \%, 10-20 \%$, $20-30 \%, 30-50 \%$, and $>50 \%$, respectively (calculated from Digital Elevation Model (DEM)).

Teff, maize, wheat, and enset are subsistence crops and the latter is mostly used by the growers (Tadesse and Tefera 2020; Woldesenbet et al. 2020). The main sources of domestic water in the area include handdug wells and ponds, seasonal streams and rarely availing groundwater wells (Fentaw and Manaye 2019b; Tadesse and Tefera 2020).

\section{Data Collection}

\section{Data preparation}

This study is a successor of the study that reported the level of risk and extent of soil loss using the Revised Universal Soil Loss Equation (RUSLE) in the same study area (Tadesse and Tefera 2020). To identify areas suitable to level Fanya juu terrace, data such as soil loss and LU/LC data that was mapped through hybrid (supervised and manual) technique from (Tadesse and Tefera 2020) and slope steepness (\%) and topographic wetness index (TWI) derived from DEM were used (Table 1).

Table 1

Data used for the study

\begin{tabular}{|llll|}
\hline Data & Unit & Resolution & Source \\
\hline Soil loss & tons/ha/yr & $30 \times 30$ & (Tadesse and Tefera 2020) \\
\hline LU/LC & Category & $30 \times 30$ & (Tadesse and Tefera 2020) \\
\hline Slope & $\%$ & $30 \times 30$ & Derived from DEM \\
\hline TWI & - & $30 \times 30$ & Derived from DEM \\
\hline DEM: sourced from https://earthexplorer.usgs.gov \\
\hline
\end{tabular}

In this study cropland suitability for level Fanya juu terrace is scaled into three categories; highly suitable, moderately suitable, and less suitable (Table 2). According to the SWC manual for development agents of Ethiopia (Hurni et al. 2016), level Fanya juu terrace is appropriate for cropland, and slope steepness between $3 \%$ and $50 \%$. Hence, gentle slope which is less sensitive for soil erosion, and very steep slope areas where experiencing instability and mass movement are excluded for better effectiveness of level Fanya juu terrace. Therefore, these slope categories are set to null (not suitable) (Table 2). 
Table 2

Suitability ranges of MCDA parameters for level Fanya juu terrace

\begin{tabular}{|llllll|}
\hline Parameters & \multicolumn{3}{l}{ Suitability level } & & \\
\cline { 2 - 5 } & $\begin{array}{l}\text { Highly } \\
\text { suitable }\end{array}$ & $\begin{array}{l}\text { Moderately } \\
\text { suitable }\end{array}$ & $\begin{array}{l}\text { Less } \\
\text { suitable }\end{array}$ & $\begin{array}{l}\text { Not suitable } \\
\text { (Null) }\end{array}$ & Remark \\
\hline $\begin{array}{l}\text { Soil loss } \\
\text { (tons/ha/yr) }\end{array}$ & $>30$ & $18-30$ & $\leq 18$ & - & (Hurni 1985) \\
\hline LU/LC & Cropland & - & -- & Other LU/LC & $\begin{array}{l}\text { (Hurni et al. } \\
\text { 2016) }\end{array}$ \\
\hline Slope \% & $3-15$ & $15-30$ & $30-50$ & $<3 \&>50$ & $\begin{array}{l}\text { (Hurni et al. } \\
\text { 2016) }\end{array}$ \\
\hline TWI & $\leq 1$ & $1-7$ & - & $\geq 7$ & - \\
\hline
\end{tabular}

The quantity of soil loss not exceeding 18 tons/ha/yr is the upper limit where production is possible in the Ethiopian highlands (Hurni 1985). Here, areas signifying a severe level of soil loss needs SWC measure and scaled to highly suitable for level Fanya juu terrace. TWI shows the level of moisture concentration (Halefom and Teshome 2019). Areas with a higher TWI value, $>7$, fell on gullies and stream channels. Therefore, these values are excluded from the analysis and set to null (not suitable) (Table 2).

Soil depths less than $50 \mathrm{~cm}$ are not suitable for level Fanya juu terrace (Hurni et al. 2016). The study area belongs to moist weyna dega and moist dega agro-ecology and the soil depth to bedrock obtained from International Soil Reference and Information Centre ranges from $1.13-1.75 \mathrm{~m}$, which are suitable for level Fanya juu terrace (Hurni et al. 2016). Therefore, because of its homogeneity across the study area, agroecology, and soil depth which are prominent to device SWC measure (Kibret et al. 2020) are excluded from the analysis.

Afterward, all variables are scaled from 1 (less suitable) to 3 (highly suitable) and exclusion of inappropriate values of variables from the analysis and then proceed to the pairwise comparison.

\section{Pairwise comparison of variables}

Using multi-criteria decision analysis (MCDA) system and analytical hierarchy process (AHP) (Saaty 2008) are recently used to identify soil erosion hotspots (Halefom and Teshome 2019) and identify exclosure-based conservation (Kibret et al. 2020). Therefore, MCDA with AHP technique was employed to assess the pairwise suitability of variables for level Fanya juu terrace using Weight Module in IDRISI Selva. Using a 1-7 standard scale, adjusting pairwise values were entered based on the level of importance till the consistency ratio is acceptable ( $<0.1)$ (Saaty 2008), the measure of pairwise agreement, is achieved. To tackle the risk of soil loss, it has given a higher weight (0.48) followed by LU/LC (0.36) (Table 3). 
Table 3

Pairwise comparison matrix to identify areas suitable for

Fanya juu terrace

\begin{tabular}{|c|c|c|c|c|c|}
\hline \multicolumn{6}{|c|}{ Fanya juu terrace } \\
\hline Variables & Soil loss & LU/LC & Slope & TWI & Weight \\
\hline Soil loss & 1 & & & & 0.48 \\
\hline LU/LC & 1 & 1 & & & 0.36 \\
\hline Slope & 0.143 & 0.33 & 1 & & 0.09 \\
\hline TWI & 0.143 & 0.2 & 1 & 1 & 0.07 \\
\hline \multicolumn{6}{|c|}{ Note: Consistency ratio $=0.03$} \\
\hline
\end{tabular}

To map area suitability for level Fanya juu terrace, layers ranked with suitability level $(\mathrm{X})$ and corresponding weight (W) were merged using a weighted sum (WS) approach (Eq. 1).

\section{$W S=\sum X^{\star} W(1)$}

In the end, cropland suitability maps for level Fanya juu terrace were generated. And the result was reclassed; $<2.146$ to less suitable, $2.146-2.528$ to moderately suitable, and $>2.528$ to highly suitable.

\section{Validation of cropland suitability for level Fanya juu terrace}

To check the consistency of modeled suitable site for level Fanya juu terrace, 42 ground-truthing points (GTPs) were collected on existing terrace structures that are maintained for a long time. Where the length of the existing terrace exceeds $30 \mathrm{~m}$, one or more GTPs were taken with a fixed length of $30 \mathrm{~m}$ difference. This has aimed to test whether areas less susceptible to soil erosion are modeled in need of level Fanya juu terrace or not? Vise-versa.

\section{Estimating expected reduction in soil loss from level Fanya juu}

Level Fanya juu terraces are the most effective SWC practice in reducing soil loss, slope gradient, and runoff (Chen et al. 2017; Subhatu et al. 2018; Sultan et al. 2018; Wolka et al. 2018; Mekonnen 2021). Corresponding with the climatic and physical setting of the study area, studies reported estimates of soil loss reduced by level Fanya juu terraces in East Africa (Herweg and Ludi 1999; Subhatu et al. 2018). Therefore, the study area has min-max ranges of elevation (1893-2513 m.a.s.I.) and rainfall (900-1400 $\mathrm{mm}$ ) were considered and the mean percentage of soil loss reduced (77\%) of Minchet catchment (Subhatu et al. 2018) and Maybar and Hunde Lafto (Herweg and Ludi 1999) were taken to estimate a potential reduction of soil loss using level Fanya juu terrace (Table 4). 
Table 4

Reports depicting the role of level Fanya juu terrace in reducing soil loss

\begin{tabular}{|c|c|c|c|c|c|}
\hline Study Sites & $\begin{array}{l}\text { Elevation } \\
(\mathrm{m})\end{array}$ & $\begin{array}{l}\text { Rainfall } \\
(\mathrm{mm})\end{array}$ & $\begin{array}{l}\text { Soil loss } \\
\text { reduced (\%) }\end{array}$ & $\begin{array}{l}\text { Rainfall } \\
\text { months }\end{array}$ & Source \\
\hline $\begin{array}{l}\text { Minchet Catchment } \\
\text { (Ethiopia) }{ }^{1}\end{array}$ & $\begin{array}{l}2430- \\
2460\end{array}$ & 1690 & 60 & 5 & $\begin{array}{l}\text { (Subhatu et al. } \\
\text { 2018) }\end{array}$ \\
\hline Maybar (Ethiopia) ${ }^{1}$ & $\begin{array}{l}2000- \\
3000\end{array}$ & 1211 & 72 & 7 & $\begin{array}{l}\text { (Herweg and } \\
\text { Ludi 1999) }\end{array}$ \\
\hline $\begin{array}{l}\text { Hunde Lafto } \\
\text { (Ethiopia) }{ }^{1}\end{array}$ & $\begin{array}{l}2000- \\
3000\end{array}$ & 935 & 100 & 6 & $\begin{array}{l}\text { (Herweg and } \\
\text { Ludi 1999) }\end{array}$ \\
\hline Afdeyu (Eritrea) $)^{2}$ & $\begin{array}{l}1000- \\
2000\end{array}$ & 382 & 83 & 3 & $\begin{array}{l}\text { (Herweg and } \\
\text { Ludi 1999) }\end{array}$ \\
\hline Gikuuri (Kenya) ${ }^{2}$ & $\begin{array}{l}1300- \\
1500\end{array}$ & $\begin{array}{l}900- \\
1200\end{array}$ & $\begin{array}{l}80(S 6-15 \%), \\
58(S>32 \%)\end{array}$ & 5 & $\begin{array}{l}\text { (Tenge et al. } \\
\text { 2011) }\end{array}$ \\
\hline
\end{tabular}

1; Used to estimate an expected percentage of soil loss would be reduced from level Fanya juu. Therefore, the calculated mean of the three percent reduction is $77 \%$.

2; not accepted because the rainfall (Afdeyu) and elevation (Gikuuri) are below the minimum range of the study area.

S: slope (\%).

\section{Result and Discussion}

Table 5 shows that the majority (78\%) of estimated soil loss was fall in a normal level of soil erosion ( $\leq$ 18 tons/ha/yr) and set to less suitable for level Fanya juu terrace. Soil loss accounting for $15 \%$, cropland (61\%), slope gradient (64\%), and TWI (39\%) are supposed to estimate and map areas in need of intervention and highly suitable for level Fanya juu terrace (Table 5; Fig. 2). Due to the pairwise importance weight given, the extents of the suitability scale of the variables (Table 5; Fig. 2) would not be consistent for the final map (Fig. 3; Table 6). 
Table 5

Extents of variables suitability class

\begin{tabular}{|c|c|c|c|c|c|c|c|c|}
\hline \multirow[t]{3}{*}{ Suitability class } & \multicolumn{8}{|l|}{ Area } \\
\hline & \multicolumn{2}{|c|}{ Soil loss } & \multicolumn{2}{|c|}{ LU/LC } & \multicolumn{2}{|l|}{ Slope } & \multicolumn{2}{|l|}{ TWI } \\
\hline & ha & $\%$ & ha & $\%$ & ha & $\%$ & ha & $\%$ \\
\hline Highly suitable & 1231 & 15 & 4922 & 61 & 5145 & 64 & 3124 & 39 \\
\hline Moderately suitable & 577 & 7 & - & - & 1806 & 22 & 4365 & 54 \\
\hline Less suitable & 6246 & 78 & - & - & 417 & 5 & - & - \\
\hline Not suitable (Null) & - & - & 3132 & 39 & 686 & 9 & 565 & 7 \\
\hline Total & 8054 & 100 & 8054 & & 8054 & 100 & 8054 & 100 \\
\hline
\end{tabular}

In recent studies reported that areas depicting a high rate of soil erosion need urgent priority and intervention (Belayneh et al. 2019; Yesuph and Dagnew 2019; Almaw et al. 2020; Ashraf 2020; Jothimani et al. 2020). Here, $15 \%$ of the study area shows $>30$ tons/ha/yr (Tadesse and Tefera 2020) which is prioritized first for level Fanya juu terrace (Table 5). Also, in Ethiopia, an extensive amount of soil erosion was reported in cropland, those needs reversing action (Gebreselassie et al. 2016; Almaw et al. 2020) (Table 5). Again for slope gradient, $64 \%$ and $22 \%$ of the study area is high to moderately suitable for level Fanya juu, respectively. In support of this, physical SWC measures are prominently effective in reducing slope gradient and increasing sediment deposition (Subhatu et al. 2017, 2018; Mekonnen 2021).

\section{Site suitability validation}

Among the 42 GTPs collected on the existing terraces, 40 (95\%) of them are fall in the range of less suitable class and the remaining 2 GTPs $(5 \%)$ are into a moderately suitable class. Here, the status of the slope around the existing terraces influenced the modeled suitability that causes $5 \%$ of GTPs are fall into a moderately suitable class.

\section{Site suitable for level Fanya juu terrace}

The weighted overlay results in Table 6 and Fig. 3 shows that $5.5 \%$ and $3.2 \%$ of the study area is urgently recommended and highly to moderately suitable for level Fanya juu terrace. In line with Fig. 2, the final suitability map (Fig. 3) attempts to subset croplands with a severe rate of soil erosion and then masked for promising relevance of level Fanya juu terrace (Table 6 and Fig. 3). 
Table 6

Extents of suitability class for level Fanya juu

terrace

\begin{tabular}{|lll|}
\hline Suitability level & Area (ha) & Area (\%) \\
\hline Highly suitable & 442 & 5.5 \\
\hline Moderately suitable & 258 & 3.2 \\
\hline Less suitable & 3286 & 40.8 \\
\hline Not suitable (Null) & 4068 & 50.5 \\
\hline Total & 8054 & 100 \\
\hline
\end{tabular}

Recent reports confirmed that appropriately executed level Fanya juu terrace has efficiently trapped sediment and soil organic matter, reduced runoff and slope gradient, and improved crop yield (Saiz et al. 2016; Aga et al. 2018; Subhatu et al. 2018; Wolka et al. 2018; Alemu and Melesse 2020; Teka et al. 2020; Mekonnen 2021). Half (50.5\%) of the study area is not applicable for level Fanya juu terrace. The reason is that this portion of the area could be either possible for bench terrace (very steep slope and/or noncropland) or soil moisture conservation measures that couldn't yield waterlogging (Hurni et al. 2016; Wolka et al. 2018).

Using similar guidelines to this study (Hurni et al. 2016) and with $90 \%$ accuracy, $8 \%$ of the total landmass, $0.4 \%$ of agricultural land, and $7.6 \%$ of non-agricultural land of Ethiopia were reported to be suitable for area exclosure (Kibret et al. 2020). The study adds that in the central rift valley lakes basin where the study area is located, $0.7 \%$ of agricultural land and $8.1 \%$ of non-agricultural land were suitable for area exclosure. This implies that the MCDA approach, among other applications, is capable to identify areas in need of interventions.

Obtaining information about area applicability for SWC measures is not a simple task, where development agents (DAs) are expected to measure and analyze landscape elements (Hurni et al. 2016). However, trained manpower and exhaustive time are necessary to suggest appropriate SWC measures. Therefore, this, MCDA, the technique has been attributed to spatial layers and decision criteria. This would have important information backing DAs to identify and easily track appropriate areas mapped for level Fanya juu terrace. Notably, before execution, this physical suitability information is a preliminary decision support tool and further ground survey and community involvement are pertinent to sustain the intervention (Wolka et al. 2018; Kibret et al. 2020). In line with that, despite its implementation and promising result on sediment depositions, terraces with wider spacing in steep slope cropland didn't reverse soil loss to a tolerable limit (Subhatu et al. 2017).

Potential reduction of soil loss from level Fanya juu terrace 
According to reference proportion (Herweg and Ludi 1999; Subhatu et al. 2018), 77\% of soil loss will be presumed to be reduced after implementation of level Fanya juu terrace (Table 7). Accordingly, in areas prominently in need of level Fanya juu terrace, the soil loss will be expected to reduce from 105,990 tons/ha/year to 4,378 tons/ha/year (Table 7).

Table 7

Expected reduction in soil loss from level Fanya juu terrace

\begin{tabular}{|c|c|c|}
\hline Level of suitability & $\begin{array}{l}\text { Soil loss (tons/ha/year) } \\
\text { (Tadesse and Tefera 2020)* }\end{array}$ & $\begin{array}{l}\text { 77\% estimated reduction } \\
\text { (tons/ha/year) }\end{array}$ \\
\hline Highly suitable & 105,990 & 24,378 \\
\hline Moderately suitable & 22,361 & 5,143 \\
\hline Less suitable & 5,625 & 1,294 \\
\hline Grand Total & 133,976 & 30,814 \\
\hline \multicolumn{3}{|c|}{ * The soil loss was quantified using the final suitability map (Fig. 3) as a mask layer. } \\
\hline \multicolumn{3}{|c|}{$\begin{array}{l}\text { However, temporal (i.e. age), spatial (i.e. agro-ecology), detail of implementation, maintenance service } \\
\text { and farmers' acceptance determines the effectiveness of SWC measure (Herweg and Ludi 1999; } \\
\text { Subhatu et al. 2017; Sultan et al. 2018; Wolka et al. 2018; Alemu and Melesse 2020; Mekonnen 2021). } \\
\text { For instance, the development of level Fanya juu terrace to bench terrace takes a minimum of } 7 \text { years } \\
\text { to a decade (Herweg and Ludi 1999; Subhatu et al. 2017). Besides, effectiveness in trapping sediment } \\
\text { decrease with increasing age of the terrace; on contrary, higher crop yield was obtained on aged } \\
\text { structures than recently constructed measures (Mekonnen 2021). The return of SWC measure couldn't } \\
\text { come into effect in a short period after execution (Wolka et al. 2018). To sustain the benefits of SWC } \\
\text { measures, regular maintenance is recommended every three to } 5 \text { years of implementation (Mekuria } \\
\text { 2020). }\end{array}$} \\
\hline
\end{tabular}

However, the ex-ante reduction on soil loss needs considerable attention in terms of technical and socioeconomic collaboration. As a result, the gradual enrichment of the level Fanya juu terrace would have a significant contribution to improving crop/biomass yield and reducing soil loss below the tolerable limit (Subhatu et al. 2018; Wolka et al. 2018; Alemu and Melesse 2020; Mekonnen 2021). In the end, level Fanya juu terrace is expected to reduce soil/sediment loss (Subhatu et al. 2017, 2018) and costs of land degradation due to soil erosion by water (Gebreselassie et al. 2016).

\section{Conclusion}

This study has sought to present areas suitable for level Fanya juu terrace using multi-criteria evaluation of four contributing parameters as soil loss, LU/LC, slope, and TWI. In addition to that potential reduction of soil, the loss was estimated using an equivalent proportion sourced from literature. The result shows that $5.5 \%, 3.2 \%$, and $40.8 \%$ of the area was highly, moderately, and less suitable for level Fanya juu terrace. The validation result indicated that $95 \%$ of GTPs collected from the existing terrace was fall into a less suitable class. And the remaining $5 \%$, with the effect of slope, falls into the moderately suitable 
class. This implies that the MCDA tool, trending a decade of application, is efficient to determine site appropriate for level Fanya juu terrace.

Frequently reported issues allied to farmers' acceptance, structure age, regular maintenance, and proper implementation are important to define the effectiveness of SWC measures. Taking into consideration these issues, level Fanya juu terrace has a $77 \%$ reported mean potential to reduce soil loss. Accordingly, level Fanya juu terrace would have the potential of reducing soil loss from 105,990 tons/ha/yr to 24,378 tons/ha/yr in areas highly susceptible to soil erosion.

Providing local-level information on the appropriateness of SWC measure is pertinent to support development agents (DAs) and make an informed decision on farmers managed croplands. Therefore, this study has provided technical information on croplands suitable for the most effective physical SWC measure, level Fanya juu terrace. Indeed, for the further effectiveness of level Fanya juu terrace, incorporating with a biological approach is importantly recommended and also practitioners need to work accordingly.

\section{Abbreviations}

AHP

Analytical Hierarchy Process

CSA

Central Statistical Agency of Ethiopia

DAs

Development Agents

DEM

Digital Elevation Model

GTPs

Ground Truthing Points

LU/LC

Land Use/Land Cover

MCDA

Multicriteria Decision Analysis

RUSLE

Revised Universal Soil Loss Equation

SWC

Soil and Water Conservation

TWI

Topographic Wetness Index

W

Weight

WS 
Weighted Sum

\section{Declarations}

\section{Ethics approval and consent to participate:}

Not applicable

Consent for publication:

Not applicable

\section{Competing interests:}

The authors declare that they have no competing

\section{Funding:}

Not applicable

\section{Authors' contributions:}

All authors read and approved the final manuscript

\section{Acknowledgements:}

Not applicable

Authors' information (optional): Not applicable

\section{References}

1. Aga AO, Chane B, Melesse AM (2018) Soil erosion modelling and risk assessment in data Scarce Rift Valley Lake Regions. Ethiopia Water 10:1-17. https://doi.org/10.3390/w10111684

2. Alemu WG, Melesse AM (2020) Impacts of longterm conservation measures on ecosystem services in Northwest Ethiopia. Int Soil Water Conserv Res 8:47-55. https://doi.org/10.1016/j.iswcr.2019.10.002

3. Almaw A, Tsunekawa A, Haregeweyn $\mathrm{N}$ et al (2020) Land susceptibility to water and wind erosion risks in the East Africa region. Sci Total Environ 703:135016. 
https://doi.org/10.1016/j.scitotenv.2019.135016

4. Ashraf A (2020) Risk modeling of soil erosion under different land use and rainfall conditions in Soan river basin, sub-Himalayan region and mitigation options. Model Earth Syst Environ 6:417428. https://doi.org/10.1007/s40808-019-00689-6

5. Assefa S, Kessler A (2018) Assessing Farmers' Willingness to Participate in Campaign-Based Watershed Management: Experiences from Boset District. Ethiopia Sustainability 10:1-15. https://doi.org/10.3390/su10124460

6. Belayneh M, Yirgu T, Tsegaye D (2019) Potential soil erosion estimation and area prioritization for better conservation planning in Gumara watershed using RUSLE and GIS techniques. Environ Syst Res 8:1-17. https://doi.org/10.1186/s40068-019-0149-x

7. Chen D, Wei W, Chen L (2017) Effects of terracing practices on water erosion control in China: A meta-analysis. Earth-Science Rev. https://doi.org/10.1016/j.earscirev.2017.08.007

8. CSA (2019) Projected Population of Ethiopia on July 2019. Addis Ababa, Ethiopia

9. Desta H, Fetene A (2020) Land-use and land-cover change in Lake Ziway watershed of the Ethiopian Central Rift Valley Region and its environmental impacts. Land use policy 96:1-12. https://doi.org/10.1016/j.landusepol.2020.104682

10. Federal Negarit Gazeta (1980) Forest and Wildlife Conservation and Development Proclamation No. 192/1980. Transitional Government of Ethiopia

11. Fentaw B, Manaye M (2019a) Hydrogeological and Hydrochemical Maps of Akaki Beseka NC 37-14 Sheet: Explanatory Notes. Geological Survey of Ethiopia, Addis Ababa

12. Fentaw B, Manaye M (2019b) Hydrogeological map of akakai beseka nc 37 - 14. Geological Survey of Ethiopia, Addis Ababa

13. Gebreselassie S, Kirui OK, Mirzabaev A (2016) Economics of Land Degradation and Improvement in Ethiopia. In: Nkonya E, Mirzabaev A, Braun J von (eds) Economics of Land Degradation and Improvement - A Global Assessment for Sustainable Development. Springer Open, New York, pp 401-430

14. Getahun E (2020) Ethiopia to grow 5 billion trees in the Second Green Legacy Campaign. In: World Agrofor. www.worldagroforestry.org. Accessed 25 Dec 2020

15. Haileslassie A, Mekuria W, Schmitter P et al (2020) Changing Agricultural Landscapes in Ethiopia: Examining Application of Adaptive Management Approach. Sustainability 12:. https://doi.org/10.3390/su12218939

16. Halefom A, Teshome A (2019) Modelling and mapping of erosion potentiality watersheds using AHP and GIS technique: a case study of Alamata Watershed, South Tigray, Ethiopia. Model Earth Syst Environ. https://doi.org/10.1007/s40808-018-00568-6

17. Herweg K, Ludi E (1999) The performance of selected soil and water conservation measures - Case studies from Ethiopia and Eritrea. Catena 36:99-114. https://doi.org/10.1016/S03418162(99)00004-1 
18. Hurni H (1985) Erosion-productivity-conservation systems in Ethiopia. In: Pla Sentis I (ed) Soil conservation and productivity, vol. $1+2$. Proceedings IV International Conference on Soil Conservation. Maracay, Venezuela, pp 654-674

19. Hurni H, Berhe W, Chadhokar P et al (2016) Soil and Water Conservation in Ethiopia: Guidelines for Development Agents, 2nd Revise. Bern, Switzerland: Centre for Development and Environment (CDE), University of Bern, with Bern Open Publishing (BOP)

20. Jothimani M, Abebe A, Dawit Z (2020) Mapping of soil erosion-prone sub-watersheds through drainage morphometric analysis and weighted sum approach: a case study of the Kulfo River basin, Rift valley, Arba Minch, Southern Ethiopia. Model Earth Syst Environ. https://doi.org/10.1007/s40808-020-00820-y

21. Kassa H (2018) Reshaping the Terrain: Landscape Restoration in Ethiopia. GLF Factsheet. CIFOR

22. Kibret KS, Haileslassie A, Mekuria Bori W, Schmitter P (2020) Multicriteria decision-support system to assess the potential of exclosure-based conservation in Ethiopia. Renew Agric Food Syst 1-15. https://doi.org/10.1017/S1742170520000034

23. Lemenih M, Kassa H (2014) Re-greening Ethiopia: History, challenges and lessons. Forests 5:18961909. https://doi.org/10.3390/f5081896

24. Matere SJ, Mbatia OLE, Nzuma JM, Nyamwaro SO (2016) Financial Benefit-cost Analysis of Terraces in Maize-pigeon pea Intercrop in Semi-arid Areas of Kenya. Agric Environ Sci 5:140-148. https://doi.org/10.15640/jaes.v5n1a14

25. Mekonnen M (2021) Impacts of soil and water conservation practices after half of a generation age, northwest highlands of Ethiopia. Soil Tillage Res 205:1-10.

https://doi.org/10.1016/j.still.2020.104755

26. Mekuria W (2020) Methods for sustaining soil and water conservation measures in Ethiopia. In: CGIAR. https://wle.cgiar.org. Accessed 25 Dec 2020

27. Musie M, Sen S, Chaubey I (2020) Hydrologic responses to climate variability and human activities in Lake Ziway Basin, Ethiopia. Water 12:1-26. https://doi.org/10.3390/w12010164

28. Saaty TL (2008) Decision making with the analytic hierarchy process. Int J Serv Sci 1:83-98. https://doi.org/10.1016/0305-0483(87)90016-8

29. Saiz G, Wandera FM, Pelster DE et al (2016) Long-term assessment of soil and water conservation measures (Fanya-juu terraces) on soil organic matter in South Eastern Kenya. Geoderma 274:1-9. https://doi.org/10.1016/j.geoderma.2016.03.022

30. Subhatu A, Lemann T, Hurni K et al (2017) Deposition of eroded soil on terraced croplands in Minchet catchment, Ethiopian Highlands. Int Soil Water Conserv Res 5:212-220. https://doi.org/10.1016/j.iswcr.2017.05.008

31. Subhatu A, Speranza Cl, Zeleke G et al (2018) Interrelationships between terrace development, topography, soil erosion, and soil dislocation by tillage in Minchet Catchment, Ethiopian Highlands. L Degrad Dev 29:3584-3594. https://doi.org/10.1002/ldr.3109 
32. Sultan D, Tsunekawa A, Haregeweyn N et al (2018) Efficiency of soil and water conservation practices in different agro-ecological environments in the Upper Blue Nile Basin of Ethiopia. J Arid Land 10:249-263. https://doi.org/10.1007/s40333-018-0097-8

33. Tadesse TB, Tefera SA (2020) Comparing potential risk of soil erosion using RUSLE and MCDA techniques in Central Ethiopia. Model Earth Syst Environ. https://doi.org/10.1007/s40808-02000881-z

34. Teka K, Haftu M, Ostwald M, Cederberg C (2020) Can integrated watershed management reduce soil erosion and improve livelihoods? A study from northern Ethiopia. Int Soil Water Conserv Res 8:266276. https://doi.org/10.1016/j.iswcr.2020.06.007

35. Tenge AJ, Sterk G, Okoba BO (2011) Farmers' Preferences and Physical Effectiveness of Soil and Water Conservation Measures in the East African Highlands. J Soc Sci 2:84-100

36. Wolancho KW (2015) Evaluating watershed management activities of campaign work in Southern nations, nationalities and peoples ' regional state of Ethiopia. Environ Syst Res 4:1-13. https://doi.org/10.1186/s40068-015-0029-y

37. Woldesenbet AB, Wudmatas SD, Denboba MA, Gebremariam AG (2020) Enset-based land use land cover change detection and its impact on soil erosion in Meki river watershed, Western Lake Ziway Sub-Basin, Central Rift Valley of Ethiopia. Environ Syst Res 9:1-23. https://doi.org/10.1186/s40068020-00198-x

38. Wolka K, Mulder J, Biazin B (2018) Effects of soil and water conservation techniques on crop yield, runoff and soil loss in Sub-Saharan Africa: A review. Agric Water Manag 207:67-79. https://doi.org/10.1016/j.agwat.2018.05.016

39. Yesuph AY, Dagnew AB (2019) Soil erosion mapping and severity analysis based on RUSLE model and local perception in the Beshillo Catchment of the Blue Nile Basin. Environ Syst Res 8:1-21. https://doi.org/10.1186/s40068-019-0145-1

\section{Figures}



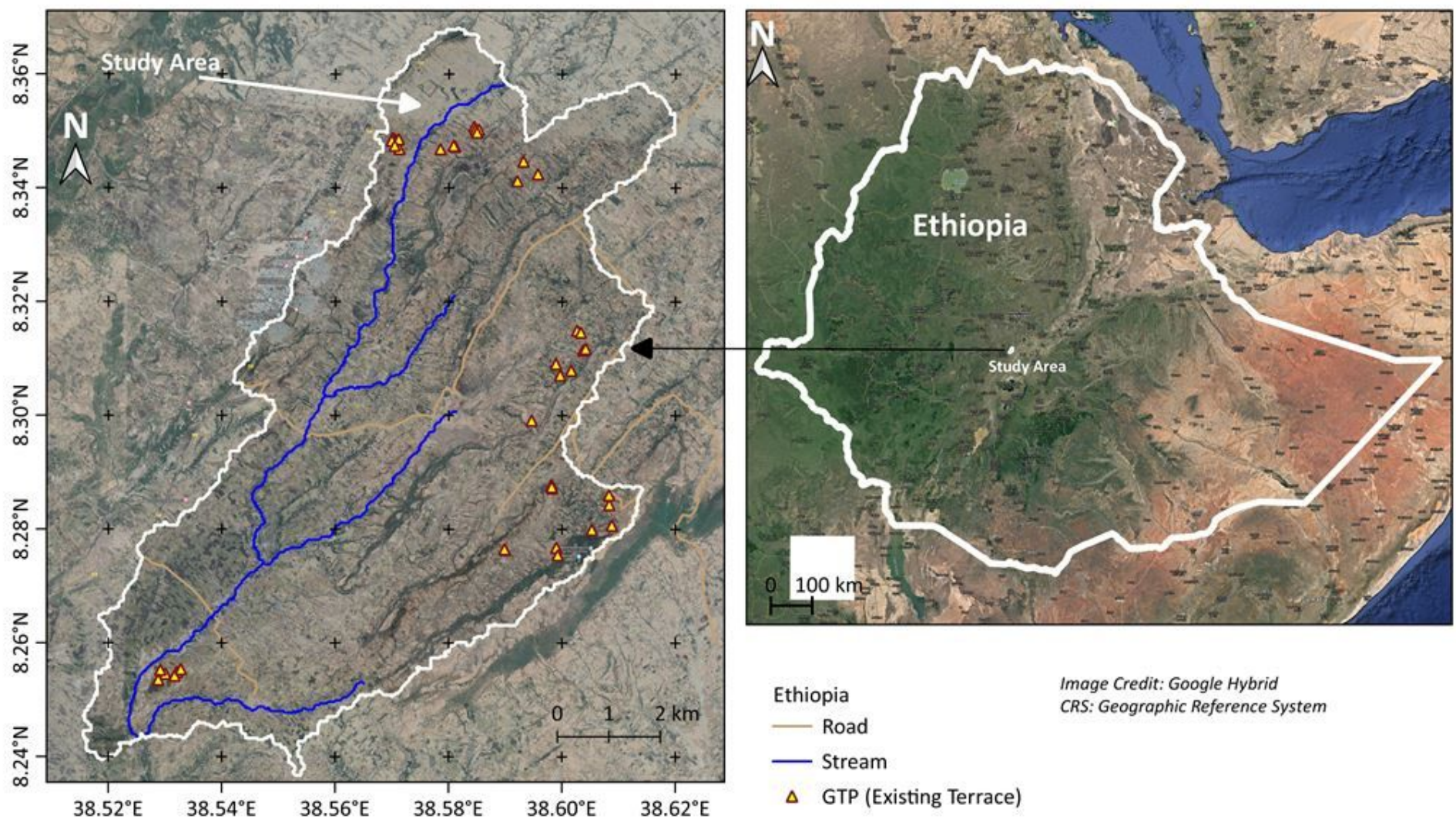

Ethiopia

Road

- Stream

$\triangle$ GTP (Existing Terrace)
Image Credit: Google Hybrid

CRS: Geographic Reference System

Figure 1

Location map of the study area 

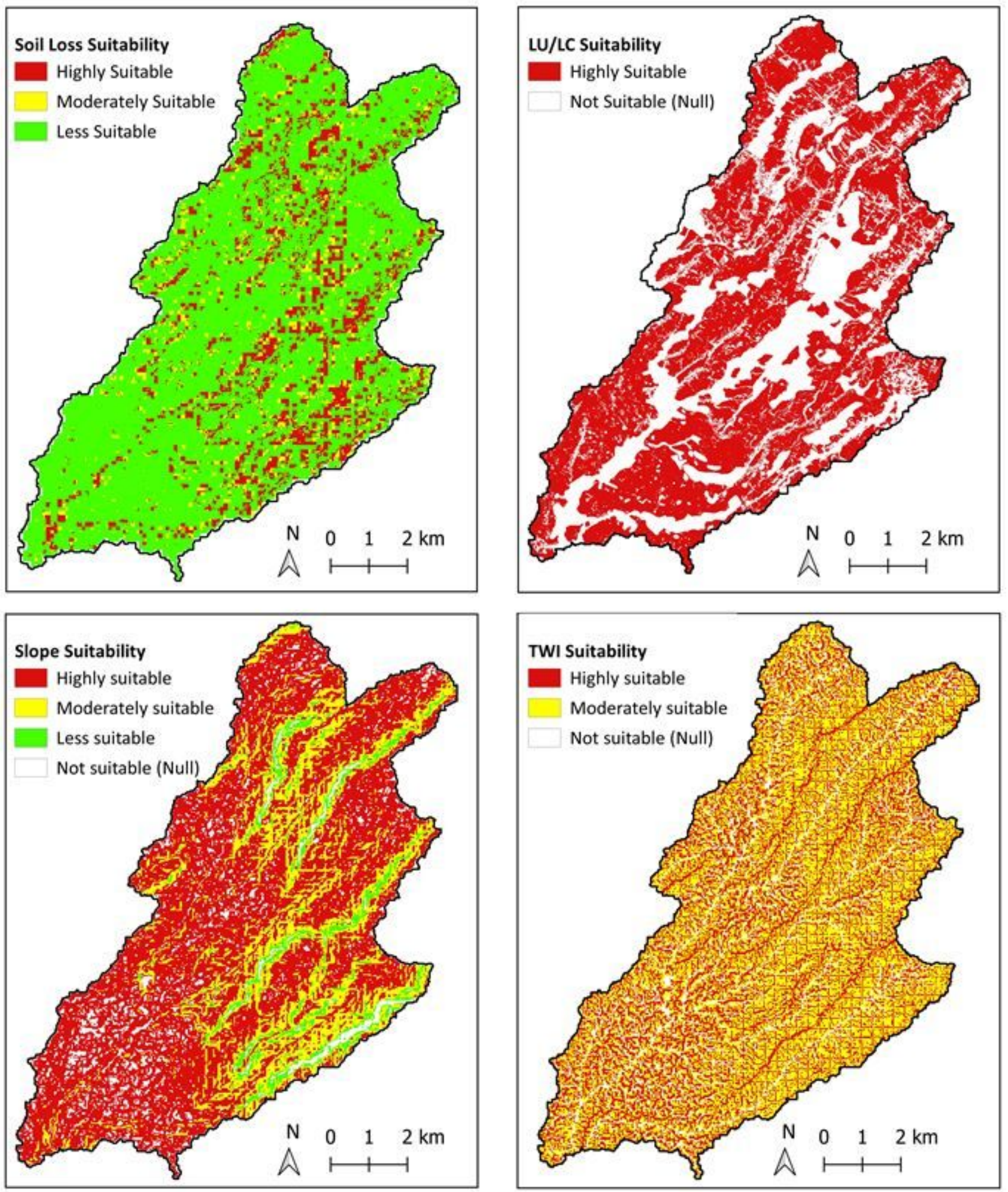

Figure 2

Suitability of variables for level Fanya juu 


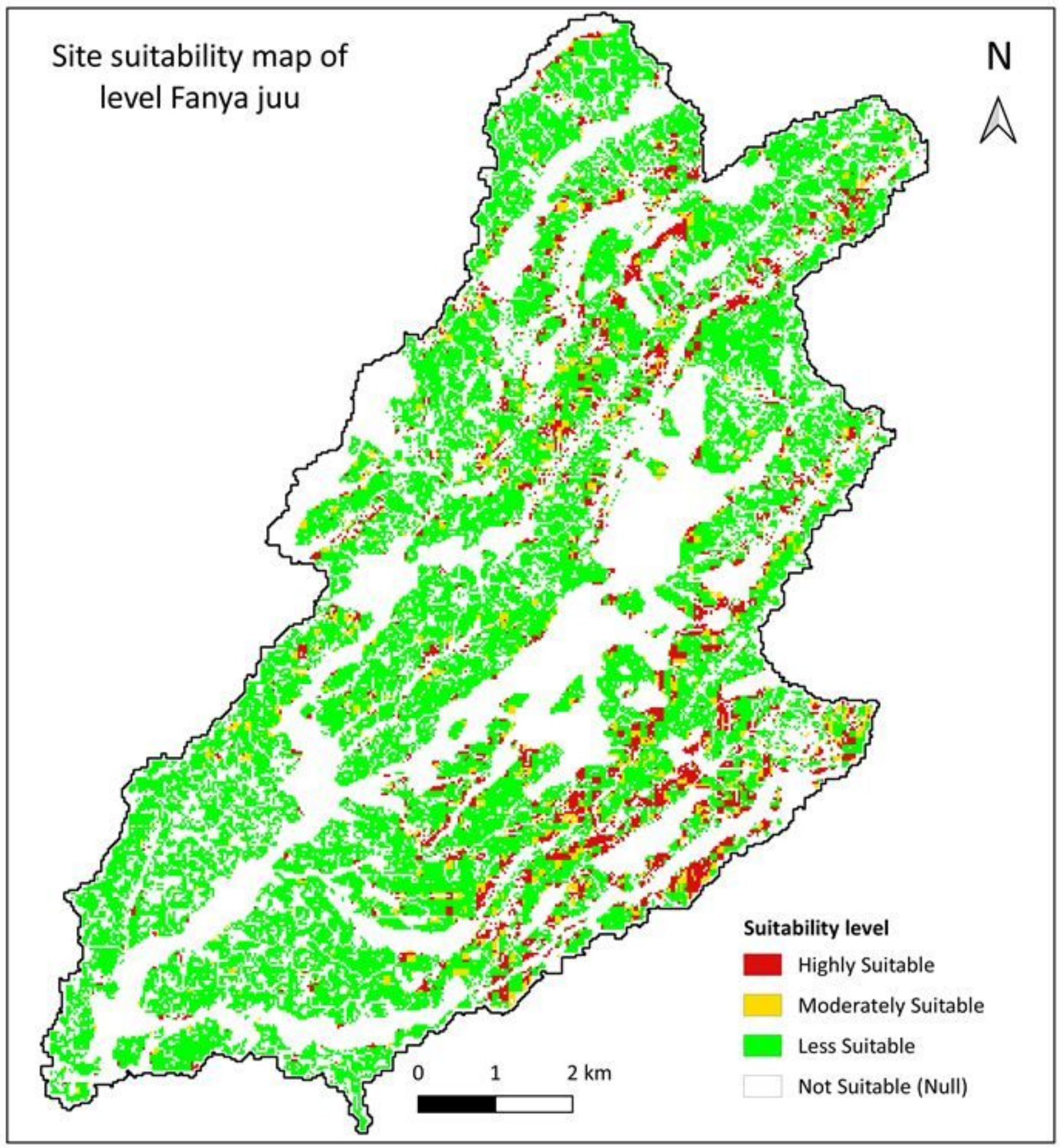

Figure 3

Site suitability map for level Fanya juu terrace 